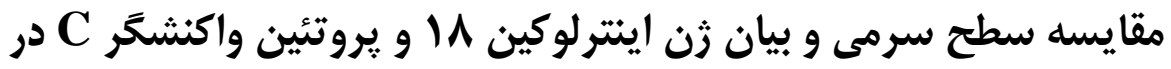

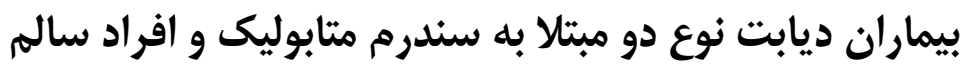

ليلا يدالهى فارسانى'، نوشا ضياء جهرمى '،"، محمد و اعظى يور "r.

() كروه زيست شناسى، دانشكده علوم : يايه، ولحد شهركرد، دانشكاه آزاد (سلامى، شهركرد، ايرلن

N) دانشكده علوم يزشكى، دانشكاه شهيد بهشتى، تهرلن، إيران

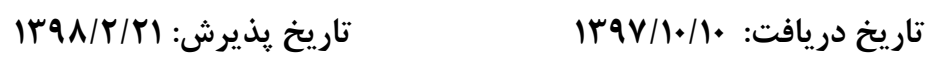

\begin{abstract}
جِكيده
مقدمه: سندرم متابوليك به عنوان يك ناهنجارى بالينى متداول، با افزايش خطر بروز بيمارى ديابت نوع r و عوامل خطر قلبى-عروقى مى باشد.

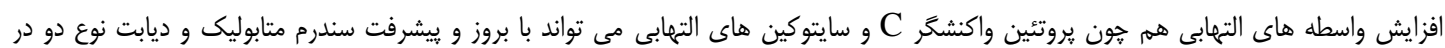
ارتباط باشد.

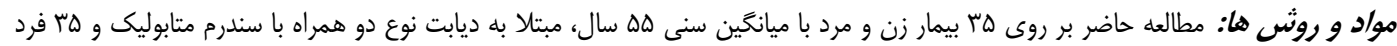

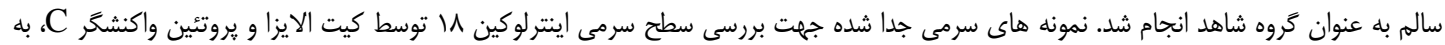

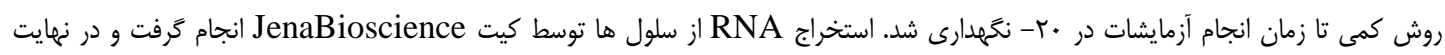

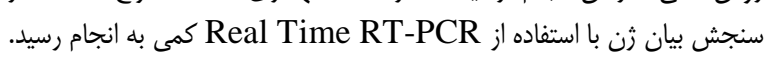

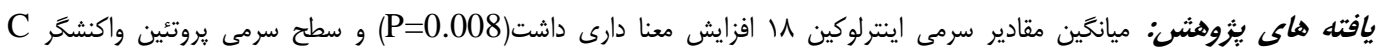

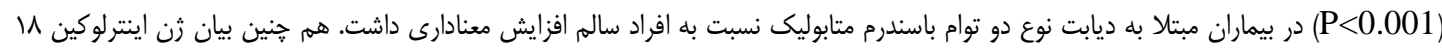

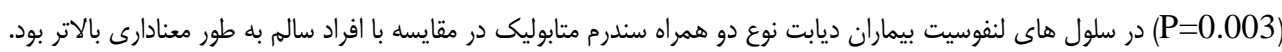

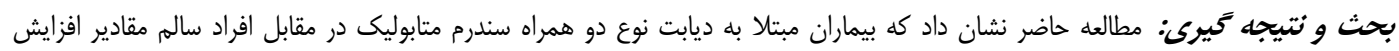

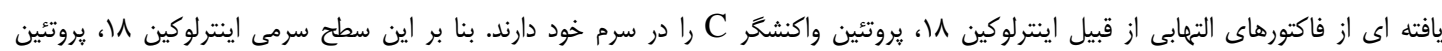

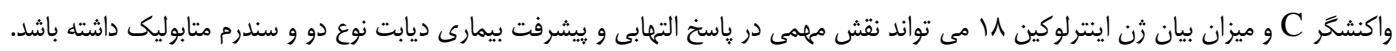

\section{وازه هاى كليدى: اينترلوكين ^\، يروتئين واكنشگر C، ديابت نوع دو، سندرم متابوليك}

* نويسنده مسئول: گروه زيست شناسى، دانشكده علوم پايه، واحد شهركرد، دانشخاه آزاد اسلامى، شهركرد، ايران

Email:n.zia@iaushk.ac.ir

Copyright (C) 2019 Journal of Ilam University of Medical Science. This is an open-access article distributed under the terms of the Creative Commons Attribution international 4.0 International License (https://creativecommons.org/licenses/by-nc/4.0/) which permits copy and redistribute the material, in any medium or format, provided the original work is properly cited. 
در افرادى است كه به لحاظ زنتيكى مستعد ابتلا به اين

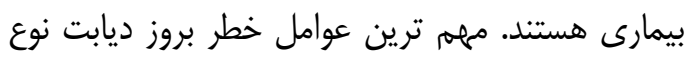

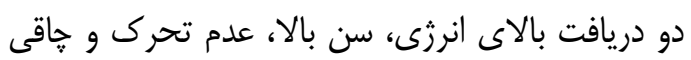

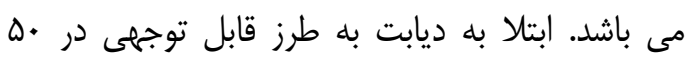

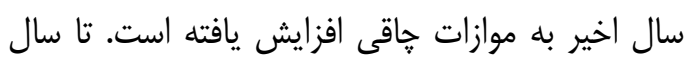

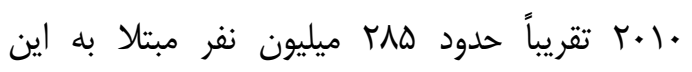

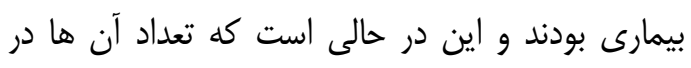

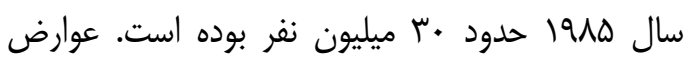

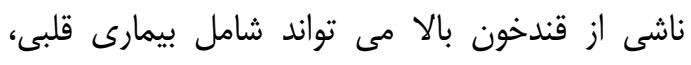

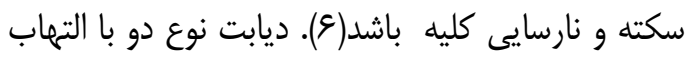

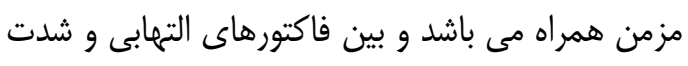

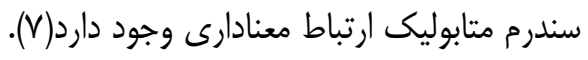

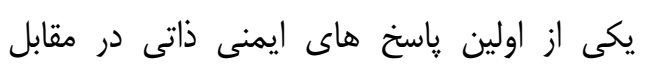

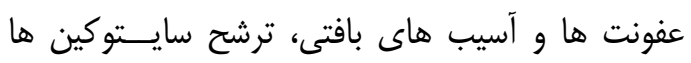

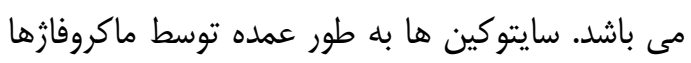

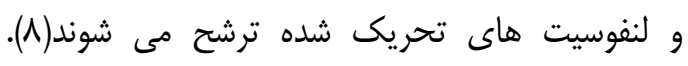

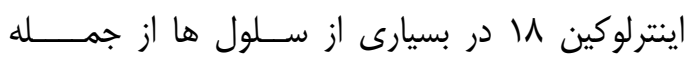
سلول هاى عصبى(دندريتيك)، سلول هاى آندوتليال،

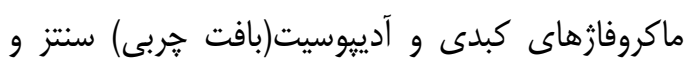

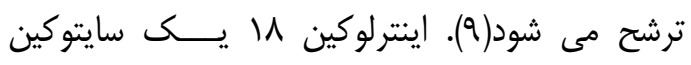

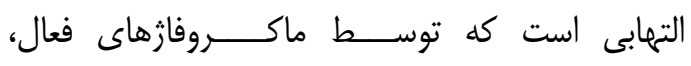

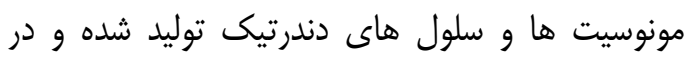
تكامل و شكل گيرى ديابت موثر است(•(1). زن

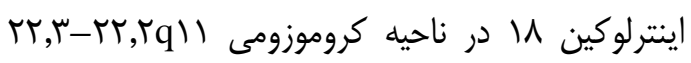
قرار دارد(1). در مراحل اوليه ابتلا به ديابت اينترلوكين

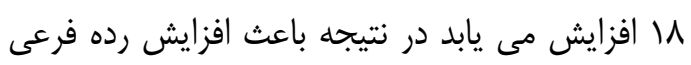

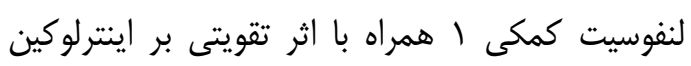

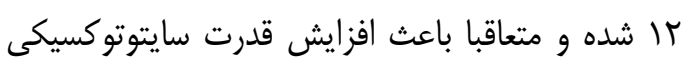

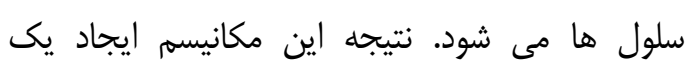

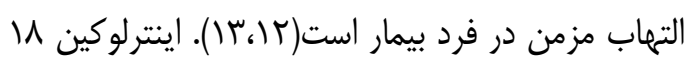

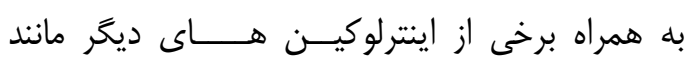

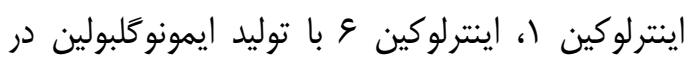

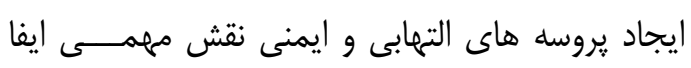

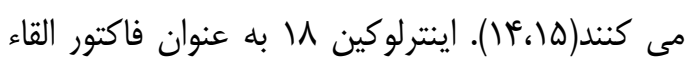

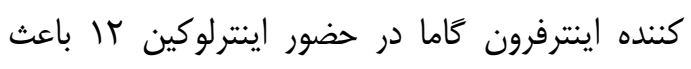

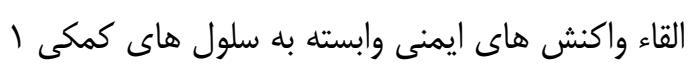

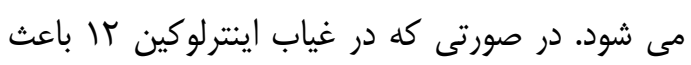

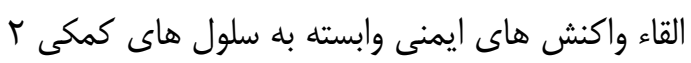

مقدمه

سندرم متابوليكى يكى از شـــايع ترين بيمارى هاى مهاى

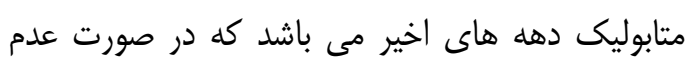

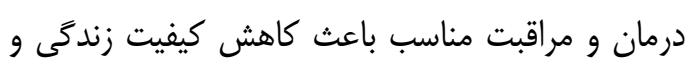

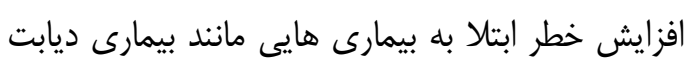

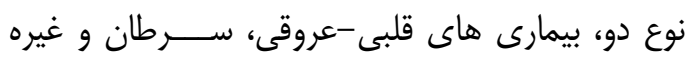
مى شود. اين بيمارى به دليل إيبدمى گسترده اضافه وزن و خاقى در سراسر جهان هر روز بيشتر از قبل مورد

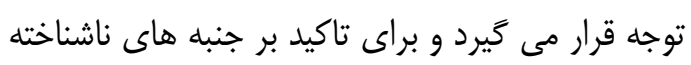

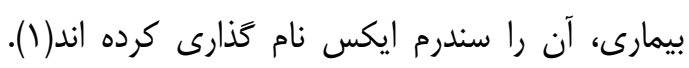

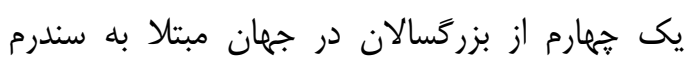

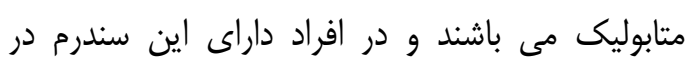

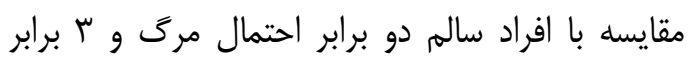

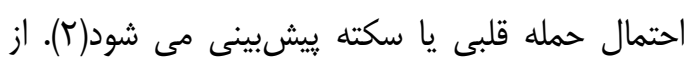

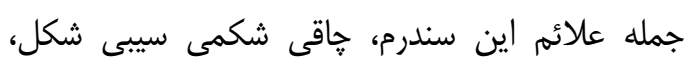

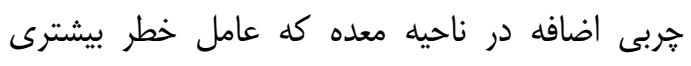
براى ابتلا به بيمارى قلبى است، تجمع حربى در دافيه باسن،

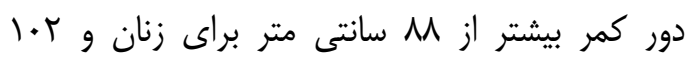

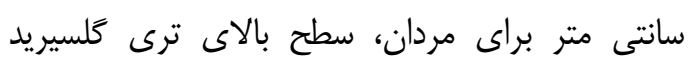
خون بالاتر از •ها ميلى گرم در دسى ليتر، سطح بائين HDL

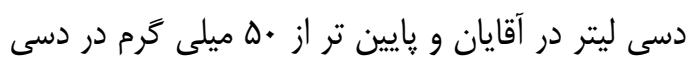

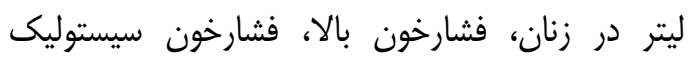

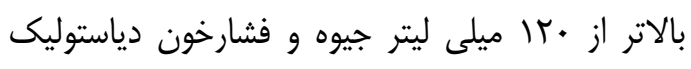

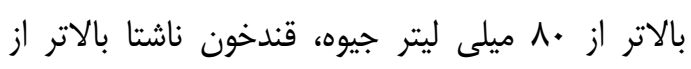

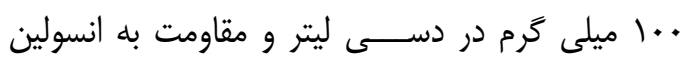

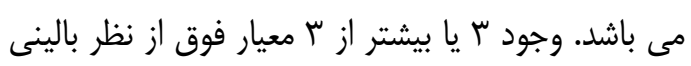
مطرح كننده سندرم متابوليك مى باشداسّ). سندرم

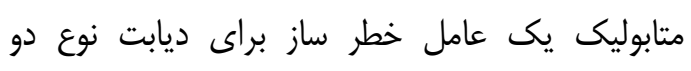

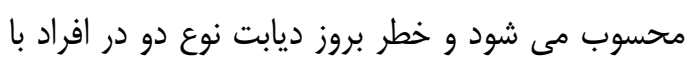

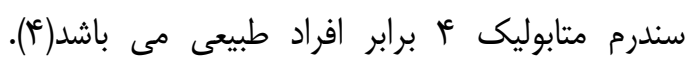
ديابت نوع دو عبارت است از اختلال در سوخت و ساز

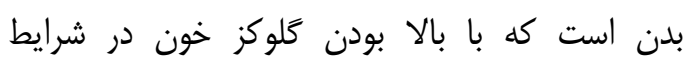
مقاومت در مقابل انسولين و كمبود نسبى انسولين بون شناسايى مى شود(ه). نشانه هاى ديابت نوع دو عبارتند

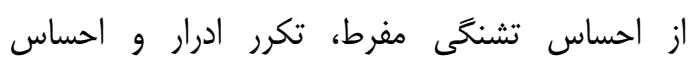

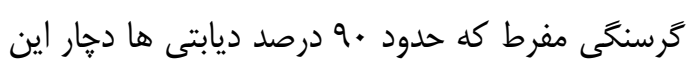

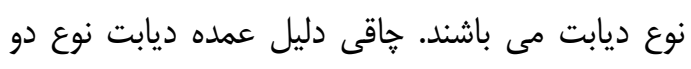


يلى اتيلن زل دار انتقال داده و براى جداسازى سرم از دستخاه سانتريفوز با نيروى نسبى برابر با g.... مدت ها دقيقه استفاد شد. نمونه هاى سرم تا زمان انجام سنجش هاى بيوشيميايى درون فريزر •r- درجه سانتى گر اد نكَهدارى شدند. جهت جداسازى لنفوســـيت از خون كامل هـ هارئل ميلى ليتر خون حاوى ماده ضد انعقاد خون تهيه شد. سبس ه ميلى ليتر نرمال سالين سرد به خون اضافه

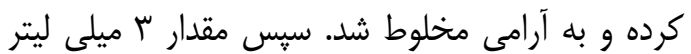
فايكول را در يك لوله سانتريفوز تميز مى ريزيم و هـ ميلى ليتر خون رقيق شده با نرمال سالين سرد را به

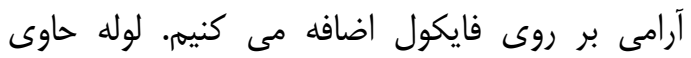
فايكول و خون را به مدت •r دقيقه سانتر يفوز مى كنيم و لايه حاوى لنفوسيت ها را به آرامى جدا مى كنيم و وارد يك لوله سانتريفوز جديد مى كنيه. معادل حجم

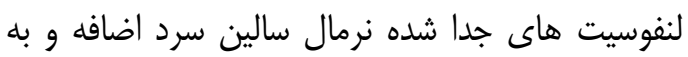

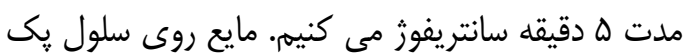
شده را بيرون ريخته و مقدار نيم ميلى ليتر نرمال سالين

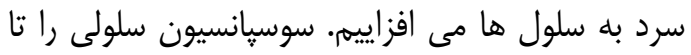

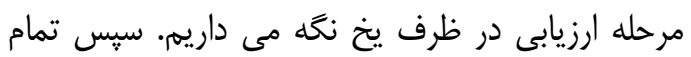

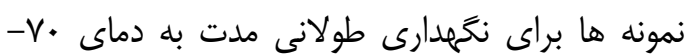

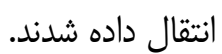

اندازه كيرى غلظت /ينترلوكين 11 در سرم: در اين

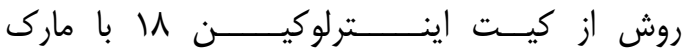
EASTBIOPHARM انجام شد. در اين سنجــــش انـــــازه كيرى غلظت اينترلوكين \\ با استفاده از تكنيك الايزاى ساندويجى لينى

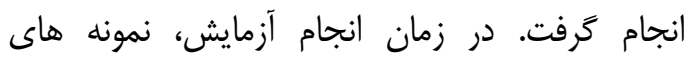

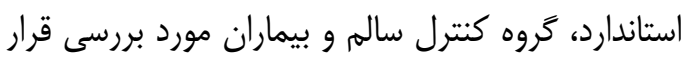
كرفت. در نهايت اطلاعات جمع آورى شده با استفاده از

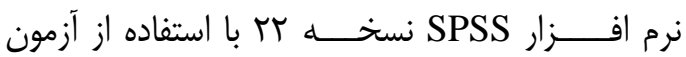
ANOVA كرديد. اندازه كيرى ميزان بروتئين واكنشَر C در سرم با

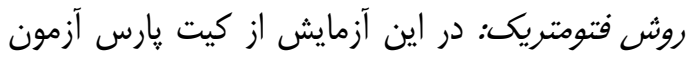

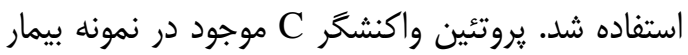

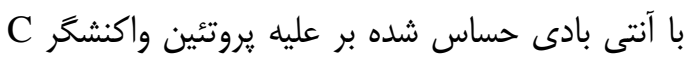

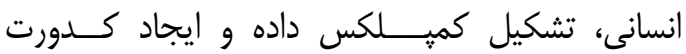

مى گردد. مطالعات صورت گرفته نشان مى دهد كه بازوفيل ها و ماست سل ها در واكنش به اينترلوكين

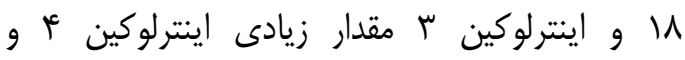

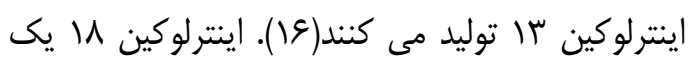
سايتوكين ييش التهابى است كه جزء خانواده اينترلوكين

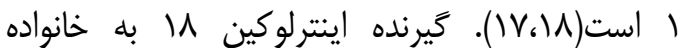

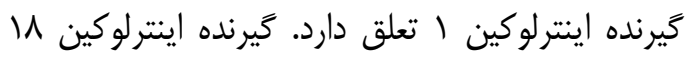

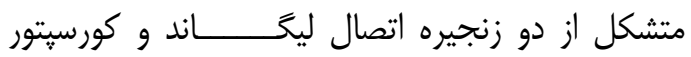

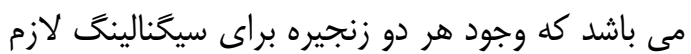

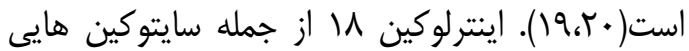

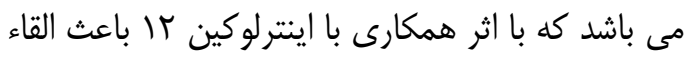

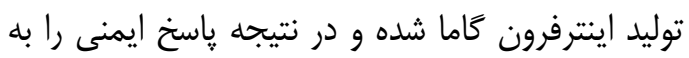

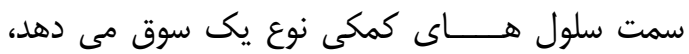

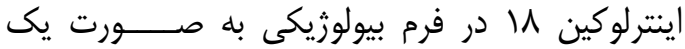
ييش ساز غير فعال ساخته مى شود و بعد از اين كه به به

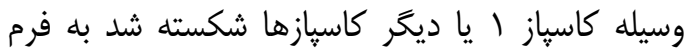
فعال تبديل مى شود(^). يروتئين واكنشى(C) يروتئين اصلى فرآيندى به نام پاسخ مرحله حاد در خون است

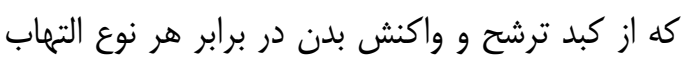

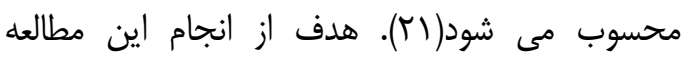
مقايسه سطح سرمى و بيان زن اينترلوكين لی يروتئين واكنشخر C در بيماران ديابت نوع دو مبتلا به

$$
\text { سندرم متابوليك و افراد سالم مىباشد. }
$$

\section{مواد و روش ها}

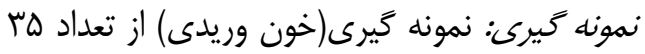
نفر(·r نفر زن و ها نفر مرد) مبتلا به ديابت نوع دو و و سندرم متابوليكى از بين بيمـــاران مراجعه كننده به آزامايشگاه هاى خصوصى و دولتى و مراكز درمانى در

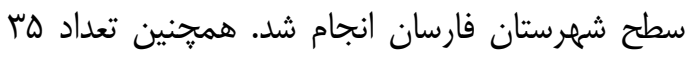

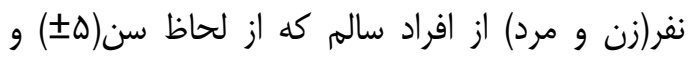
جنس با گروه بيمار، همسان سازى شده بودند، به

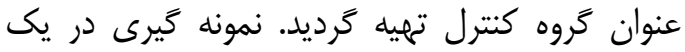

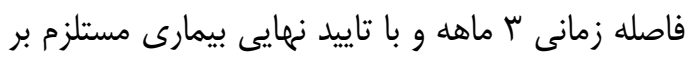
بيمارى ديابت نوع دو و سندرم متابوليك انجام ترفت معيارهاى ورود بيماران در اين مطالعه تاييد يزشك و دئو عدم وجود بيمارى هــــاى ديخر بود. به علاوه گروها

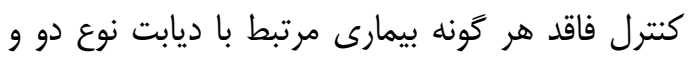

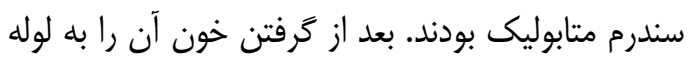


قرار گرفت. RNA تام سلولى توسط كيت شركت تاكارا

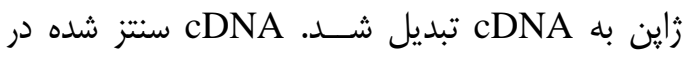

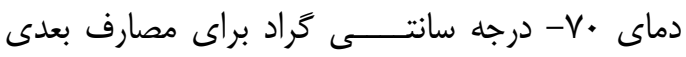

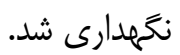
برايمرها: در اين مطالعه زن IL-18 به عنوان زن

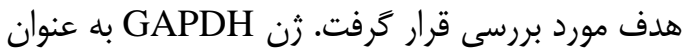

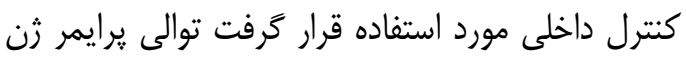

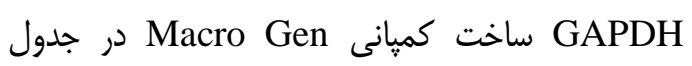
شماره ا آورده شده است.
مى نمايد. مقدار كدورت ايجاد شده با مقدار يروتئين واكنشخر C موجود در نمونه بيمار رابطه مستقيم دارد. استخراج RNA و تهيه

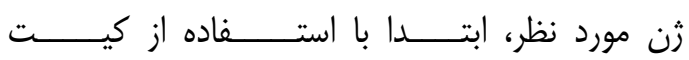
RNA JenaBioscience استخراج شد. براى به حداقل رساندن فعاليت آنزيم الز المام

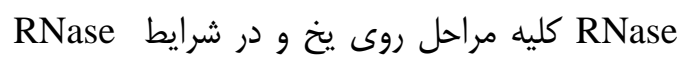
انجام گرفت. كميت RNA free

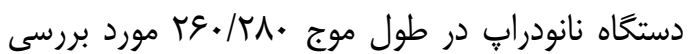

\begin{tabular}{ccc}
\multicolumn{3}{c}{ جدول شماره l. توالى يرايمرها } \\
\hline GAPDH-Forward & 5'-GGAAGGTGA & Tm \\
& AGGTCGGAGTC-3' & 62.5 \\
\hline GAPDH-Reverse & 5'-TCAGCCTTG & Tm \\
& ACGGTGCCATG-3' & 62.5 \\
IL-18- Forward & 5'-GACGCATG & Tm \\
& CCCTCAATCC-3' & 58.4 \\
\hline IL-18- Reverse & 5'-CTAGAGCGC & Tm \\
& AATGGTGCAATC-3' & 61.3 \\
\hline
\end{tabular}

غلظت ه ييكومولار، ا ميكروليتر از cDNA الخو و 9 ميكروليتر RNase-free water بود. نمونه مورد نظر

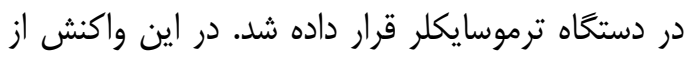

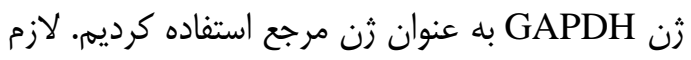

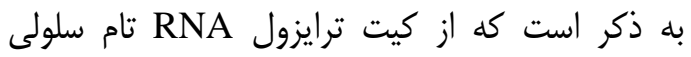
استخراج و بعد از آن با استفاده از كيت تاكارا نمونه ها تاني

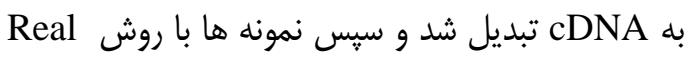

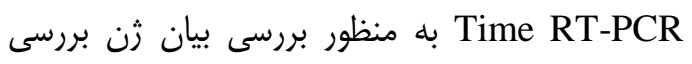

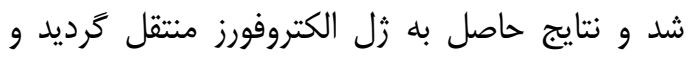
باند تشكيل شده مشاهده شد. بعد از اتمام واكنش Real timeRT- PCR صورت جداكانه به دست آمد كه با مقايسه سيكل آستانه زن مورد نظر با زن مرجع(Housekeeping)، ميزان بيان زن مورد نظر را به صــورت كمى از

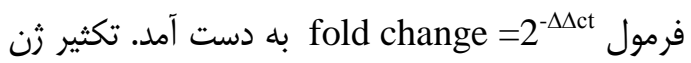

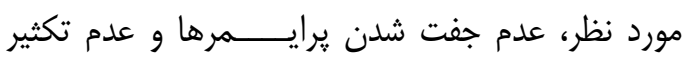
غير اختصاصى براى هر ثن با استفاده از منحنى تكثير

$$
\text { تعيين شد(نمودار شماره ()). }
$$

واكنش Real Time RT- PCR: در اين روش از يك رنح اختصاصى DNA دو رشته ایى به نام

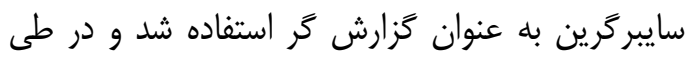

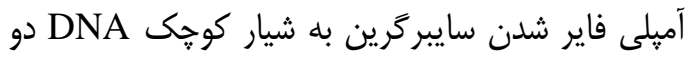
رشته اى متصل مى شود و در اثر تهيج از خود نور ساطع مى كند بنا بر اين با افزايش محصول مئ ميزان

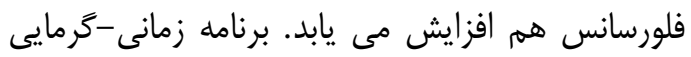

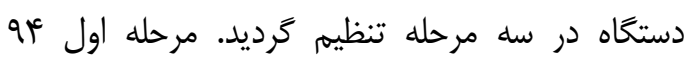

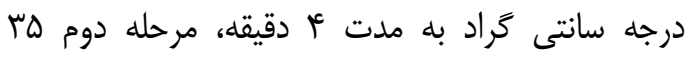
سيكل كه شامل عاو درجه به مدت •ب ثانيه جهت واسرشتخى، اع درجه سانتى گراد به مدت مات •ب ثات ثانيه

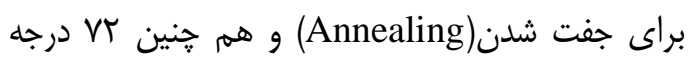

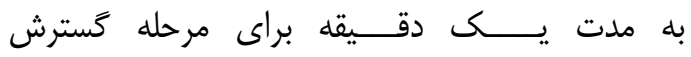
انجام شد. اين واكنــش ها در حجم (Extension)

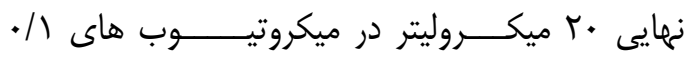

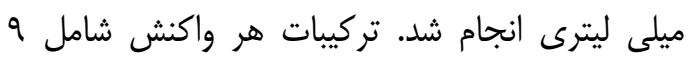
ميكروليتر از مئل ميكروليتر از هر يك از يرايمرهاى رفت و برگشت با 


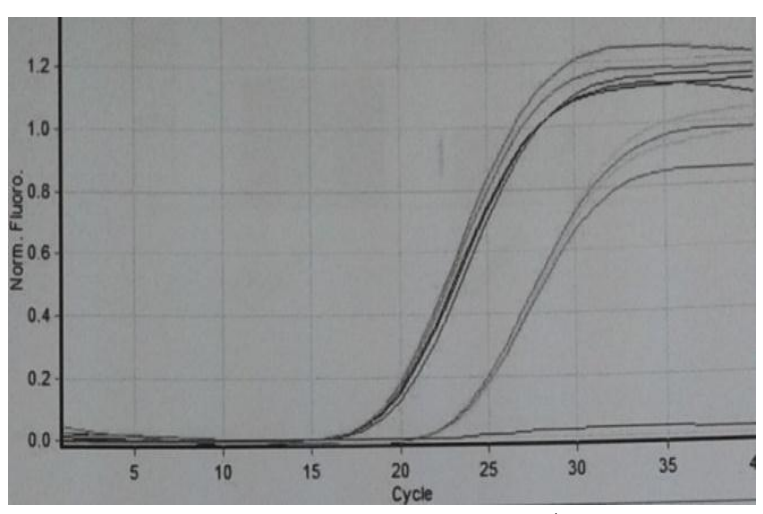

نمودار شماره (. منحنى تكثير زن اينترلوكين 11

قطعى بيمارى و هـ نفر زن و مرد سالم انجام شد.

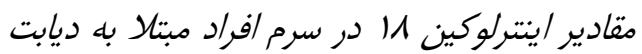

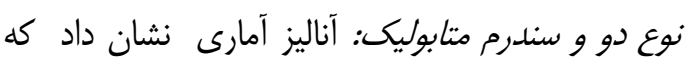

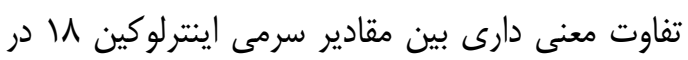

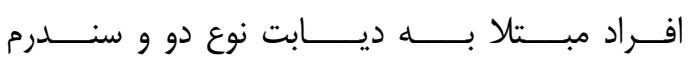

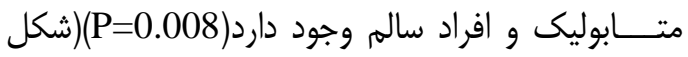

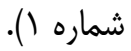

در نهايت اطلاعات جمع آورى شده با استفاده از

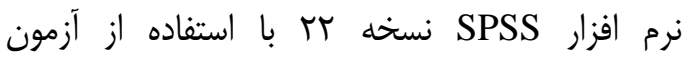
ANOVA كرديد. يافته هاى يزوديل

مطالعه حاضر بر روى هَّ نفر زن و مردئ مرد مبتلا به

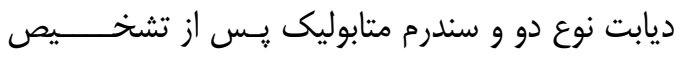

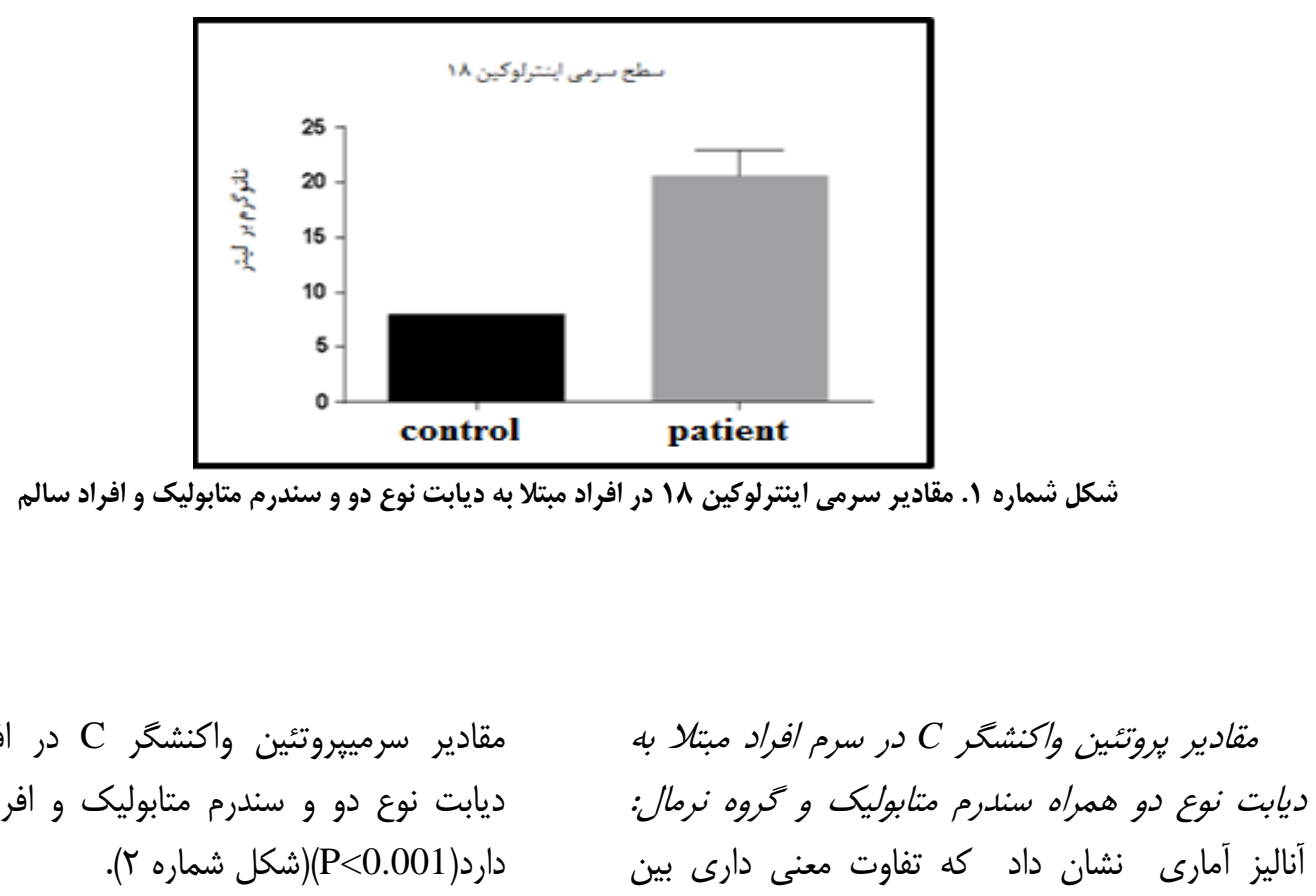

مقادير سرمييروتئين واكنشكر C در افراد مبتلا به ديابت نوع دو و سندرم متابوليك و افراد سالم وجود دارد( P<0.001)(شكل شماره ؟ ).

آناليز آمارى نشان داد كه تفاوت معنى دارى بين 


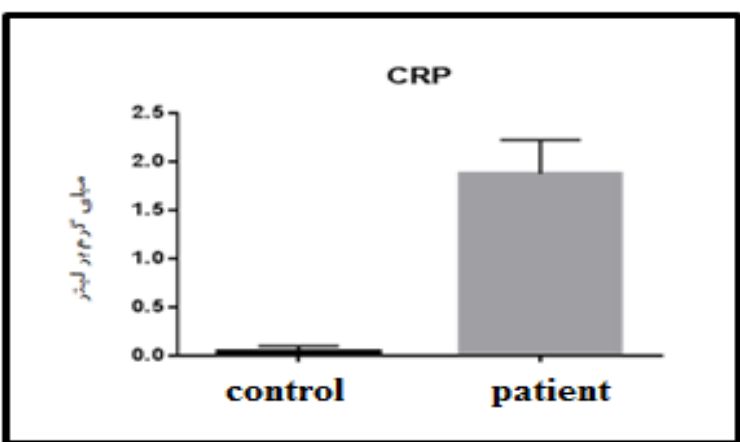

شكل شماره r. مقادير سرمى يروتئين واكنشكَر C در تَروه مبتلا به ديابت نوع دو همر اه سندرم متابوليك و افراد سالم

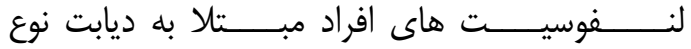

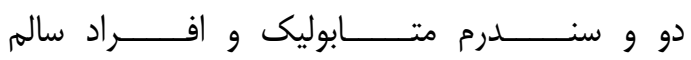

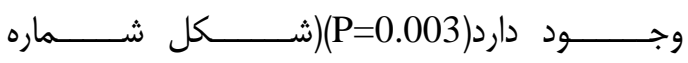
. $\left(\mu^{\mu}\right.$
مقادير بيان ثن /ينترلوكين 11 در لنفوسيت هاى

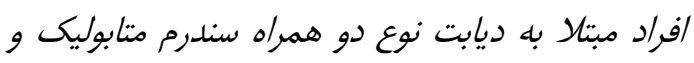

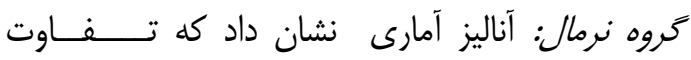

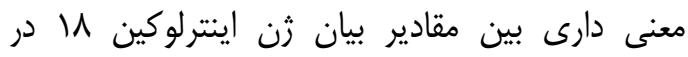

شكل شماره r. مقادير بيان زن اينترلوكين ه/ در لنفوسيت هاى كروه مبتلا به ديابت نوع دو همر اه سندرم متابوليك و افراد سالم

ساختارى به اينترلوكين ا شبيه است، اما برخلاف

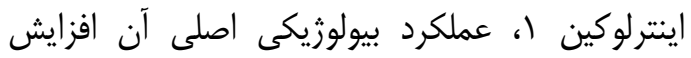
توليد IFN- به وسيله سلول هاى T T و القاى تمايز سلول هاى TCD4 توليدكنتده IFN-

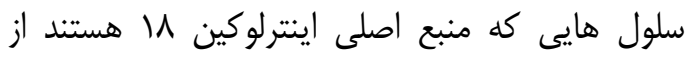

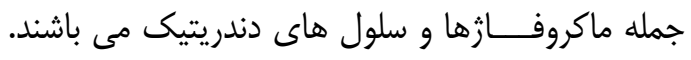

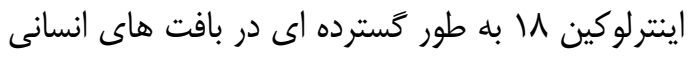

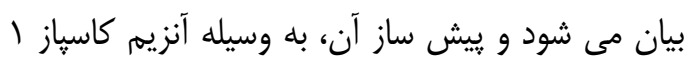

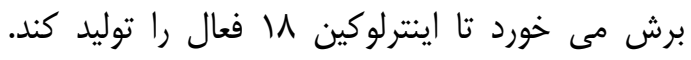

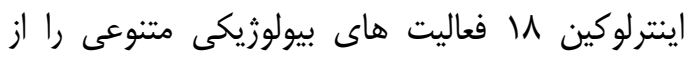

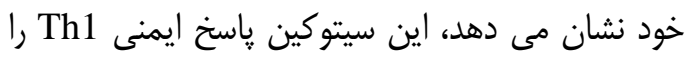

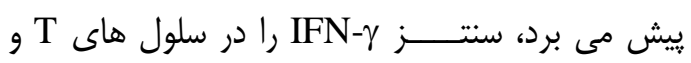
سلول هاى كشنده طبيعى تحريك مى كند سند و فعاليت سيتوتوكسيى سلول هاى كشنده طبيعى را از طريق تحني
بحث و نتيجه كيرى

يكى از اولين ياسخ هائه ايميرى ايمنى ذاتى در مقابل عفونت ها و آسيب هاى بافتى، ترشح سايتوكين ها

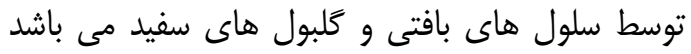

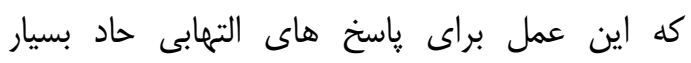

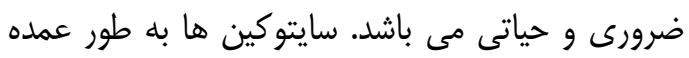
توسط ماكروفازها و لنفوسيت هاى تحريك شائ شده ترشح

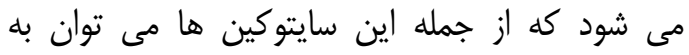

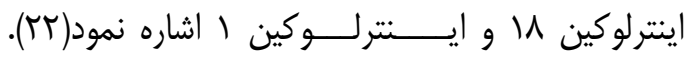

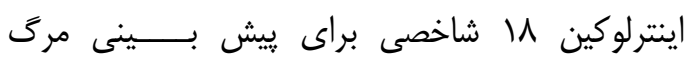

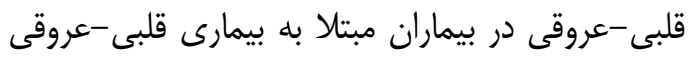
بوده و در بروز ديابت نوع دو نقش اساسى دارد(بآ).

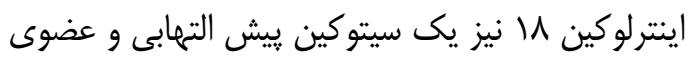

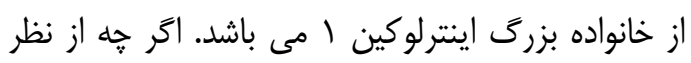


اينترلوكين \| به عنوان يك ييش بينى كننده قوى حوادث قلبى-عروقى در مردان سالمند مبتلا به سندرم بندئ

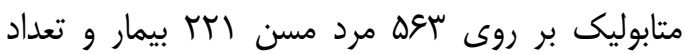

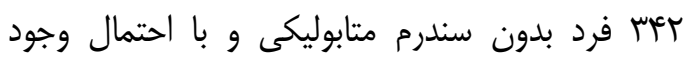
ماركرهاى التهابى با اندازهيرى اينترلوكين \ا در سرم اين بيماران دريافتند كه سطح سرمى اينترلوكين 11 و

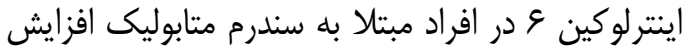

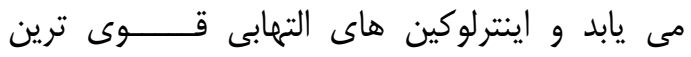

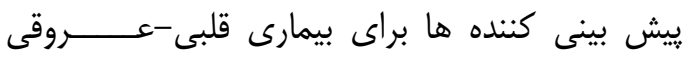
مى باشند. از سوى ديكر ارتباط معنى دارى بين كلوكز

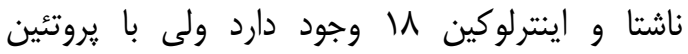
واكنشخر C ارتباطى ديده نشد. افزايش كلوكز ناشتا

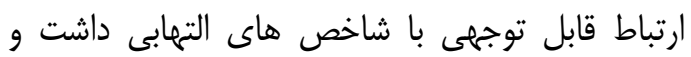

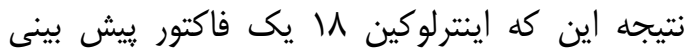
كننده براى حوادث قلبى-عروقى در افراد مبتلا به به سندرم متابوليك است. يافته ها نشان داد كه اثر متقابل ديل دراد مهار قندخون و واسطه هاى التهابى در ييش بيش بينى بيمارى هاى قلبى-عروقى وجود دارد كه اين تحقيق با نتايج مطالعات حاضر هم خوانى داشت(TV). اينترلوكين

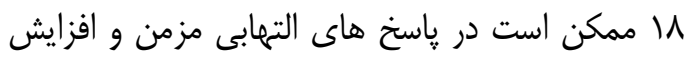

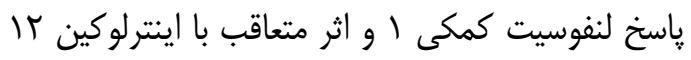
در ديابت نوع دو و سندرم متابوليك نقش مهمى ايفا كند. هم هنين اين اينترلوكين ممكن است در تشديد اين بيمارى ها نقش داشته باشد. در مراحل اوليه ابتلا

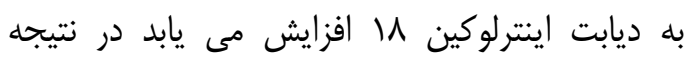
باعث افزايش رده فرعى لنفوسيت كمكى الهمراه با با اثر

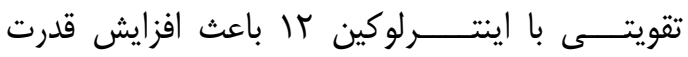
سايتوتوكسيكى سلول ها مى شود نتيجه اين مكانيسم

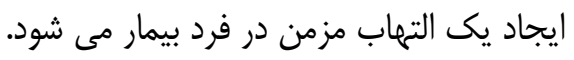

\section{سياسگز ارى}

اين مقاله بركرفته از پايان نامه كارشناسى ارشد

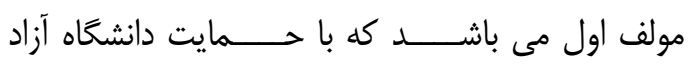

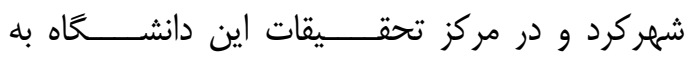

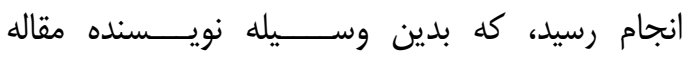
مراتب تشكر و قدردانى خود را از اين دانشعاه اعلام مى نمايد.
تنظيم ليكاند(Fas) افز ايش مى دهد(بآ). در اين مطالعه سطح رونوشت ايتترلوكين \1 در لنفوسيت هاى بيماران ديابت نوع دو و سندرم متابوليك افزايش داشت. اين رين

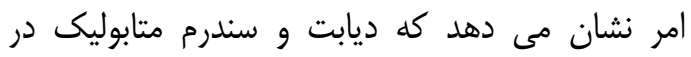

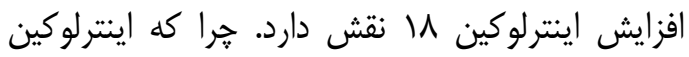

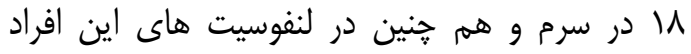

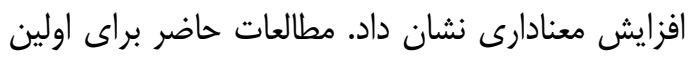

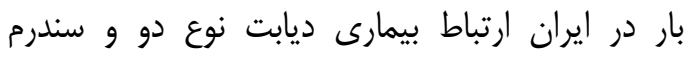

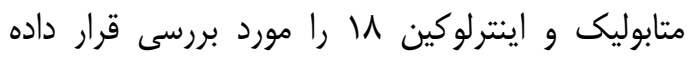
است. مطالعات بسيارى به خصوص در كشورهاى آسيايى انجام كرفته، طى مطالعه اى كه در سال هـ..r

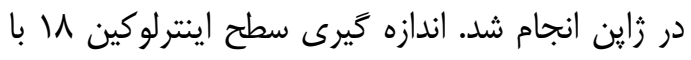
روش الايزا بر روى هشتاد و دو فرد زاينى مبتلا به إنه

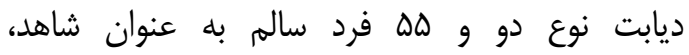

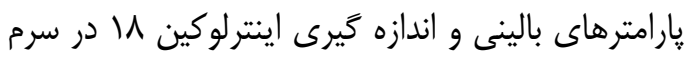

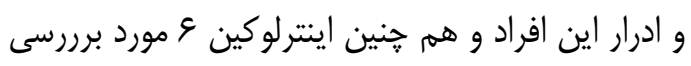

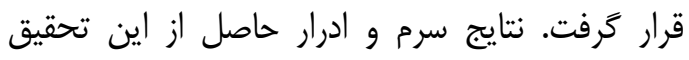

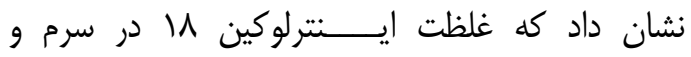

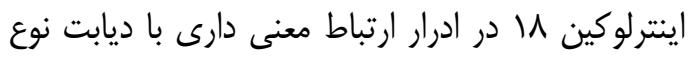

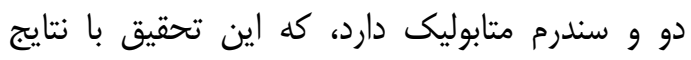

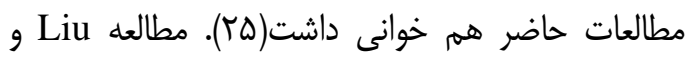

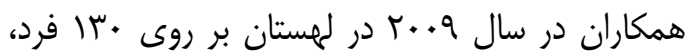

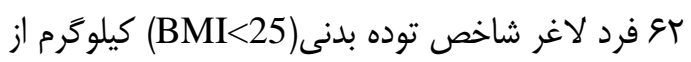

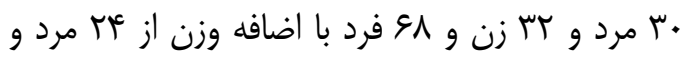

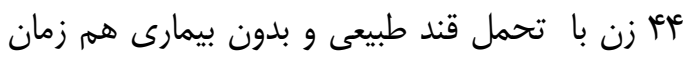

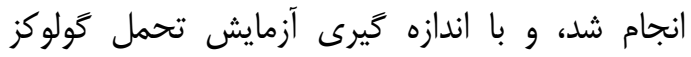

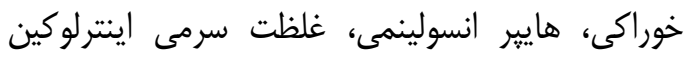
11، اينترلوكين و، كيرنده هاى فاكتور تومور نكروز آلفا و سطح آدييونكتين در سرم اين افراد با روش الايزا

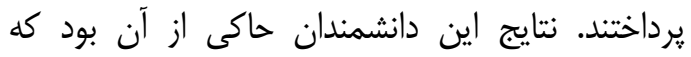
سطح سرمى اينترلوكين \\ با سطح سرمى آدييونكتين انين

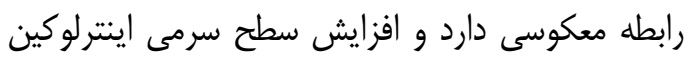

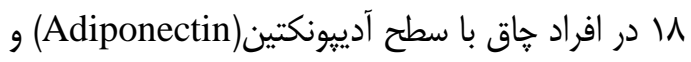
حساسيت به انسولين ارتباط معنى دارى دارد كه اين

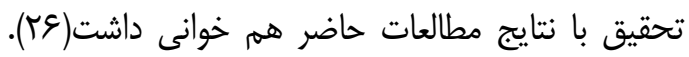

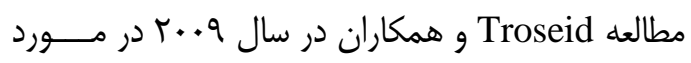


References

1. Aguilarsalinas CA, Rojas R, Gomezperez FJ, Mehta R, Franco A, Olaiz G, et al. The metabolic syndrome a concept hard to define. Arch Med Res2005; 36:223-31. doi: org/10.1016/j.arcmed.2004.12.003.

2. Aiello LP, Avery RL, Arrigg PG, Keyt BA, Jampel HD, Shah ST, et al. Vascular endothelial growth factor in ocular fluid of patients with diabetic retinopathy and other retinal disorders. New England J Med1994; 331:1480-7. doi: 10.1056/NEJM19941201 3312203.

3. Schrier R. Effect of blood pressure control on diabetic microvascular complications in patients with hypertension and type 2 diabetes. Diab Care2000; 23: 5464.

4. Guerreroromero F, Rodriguez M, Fuentes R, Guillen MC, Ortiz M, Abundis E, et al. Prediabetes and its relationship with obesity in Mexican adults the Mexican diabetes prevention study. Metab Syn Rel Disord2008; 6:15-23. doi: org/10.1089/met.2007.0020.

5. Kumar V, Abbas AK, Fausto N, Aster JC. Robbins and cotran pathologic basis of disease professional. $1^{\text {th }}$ ed. Elsevier Health Sci Publication. 2014; P.123-234.

6. Fasanmade O, Odeniyi I, Ogbera A. Diabetic ketoacidosis diagnosis and management. Af J Med Sci2008; 37:99105.

7. Wilund KR. Is the anti inflammatory effect of regular exercise responsible for reduced cardiovascular disease? Clin Sci2007; 112:543-55. doi: 10.1042/CS20060368.

8. Thorand B, Kolb H, Baumert J, Koenig $\mathrm{W}$, Chambless L, Meisinger $\mathrm{C}$, et al. Elevated levels of interleukin 18 predict the development of type 2 diabetes results from the MONICA/KORA augsburg study 19842002. Diabetes2005; 54:2932-8. doi: org/10.2337/diabetes. 54. 10.2932.

9. Kapoor M, Pelletier J, Lajeunesse D, Pelletier JP, Fahmi H. Role of proinflammatory cytokines in the pathophysiology of osteoarthritis. Nature Rev Rheumatol2011; 7:33.

10. Pasdar Y, Moridi S, Najafi F, Niazi P, Heidary M. [The effect of nutritional intervention and physical activities on weight reduction]. J Kermanshah Uni Med Sci2012; 15:34-38. (Persian)
11. Zyberk C, Joosten LA, Helsen MM, Sattonnetroche P, Siegfried C, Alouani S, et al. Therapeutic effect of neutralizing endogenous IL 18 activity in the collagen induced model of arthritis. J Clin Invest2001; 108:1825-32.

12. Reaven GM. Role of insulin resistance in human disease. Diabetes 1988; 37:1595607. doi: org/10.2337/diab.37.12.1595.

13. Schaumberg DA, Glynn RJ, Jenkins AJ, Lyons TJ, Rifai N, Manson JE, et al. Effect of intensive glycemic control on levels of markers of inflammation in type 1 diabetes mellitus in the diabetes control and complications trial. Circulation2005; 111:2446-53. doi: org/10. 1161/01.CIR.0000165064.31505.3B

14. Selvaraj N, Bobby Z, Sridhar M. Oxidative stress does it play a role in the genesis of early glycated proteins? Med Hyp2008; 70:265-8. doi: org/10.1016/j.mehy. 2007. 04. 049.

15. Shafiee G, Hadaegh F, Azizi F. Comparison of waist to height ratio and body mass index for prediction of type 2 diabetes mellitus risk in women Tehran lipid and glucose study. Iranian $\mathbf{J}$ Endocrinol Metab2009; 11:121-6.

16. Sharma SK, Ghimire A, Radhakrishnan J, Thapa L, Shrestha NR, Paudel N, et al. Prevalence of hypertension obesity diabetes and metabolic syndrome in Nepal. Int $\mathbf{J}$ Hyperten 2011; 2011. doi:10.4061/2011/821971.

17. Sprague AH, Khalil RA. Inflammatory cytokines in vascular dysfunction and vascular disease. Biochem Pharmacol2009; 78:539-52.

doi.org/10.1016/j.bcp.2009.04.029

18. Stensvold D, Slordahl SA, Wisloff U. Effect of exercise training on inflammation status among people with metabolic syndrome. Metab Syn Rel Disord2012; 10:267-72. doi.org/10.1089/met.2011.0140. 19. Szeszko JS, Howson JM, Cooper JD, Walker NM, Twells RC, Stevens HE, et al. Analysis of polymorphisms of the interleukin 18 gene in type 1 diabetes and hardy weinberg equilibrium testing. Diabetes2006; 55:559-62. doi: org/10.2337/diabetes.55.02.06.db05-0826

20. Thompson S, Humphries S. Interleukin 18 genetics and inflammatory disease susceptibility. Gen Immun2007; 8:91. 
21. Ramezanpour MR, Hejazi SM, Hosseinnezhad M. [The Comparison of HSCRP TG LDL-c and HDL-c in Active and Non Active Middle aged Women]. Med J Mashhad Uni Sci2013; 56:93-8. (Persian) 22. Pankow JS, Jacobs DR, Steinberger J, Moran A, Sinaiko AR. Insulin resistance and cardiovascular disease risk factors in children of parents with the insulin resistance metabolic syndrome. Diabetes Care2004; 27:775-80. doi: org/10.2337/diacare.27.3.775.

23. Zirlik A, Abdullah SM, Gerdes N, Macfarlane L, Schonbeck U, Khera A, et al. Interleukin 18 the metabolic syndrome, and subclinical atherosclerosis results from the Dallas heart study. Arteriosclerosis Thromb Vascul Biol2007; 27:2043-9. doi: org/10.1161/ATVBAHA.107.149484.

24. Rooney $\mathrm{T}$, Murphy E, Benito M, Lombard P, Fitzgerald O, Dayer J, et al. Synovial tissue interleukin 18 expression and the response to treatment in patients with inflammatory arthritis. Annal Rheum Dis2004; 63:1393-8. doi: org/10.1136/ard.2003.016428.

25. Nakamura A, Shikata K, Hiramatsu M, Nakatou T, Kitamura T, Wada $\mathrm{J}$, et al. Serum interleukin 18 levels are associated with nephropathy and atherosclerosis in Japanese patients with type 2 diabetes. Diabetes Care2005; 28:2890-5. doi: org/10.2337/diacare.28.12. 2890.

26. Liu SW, Qiao SB, Yuan JS, Liu DQ. Association of plasma visfatin levels with inflammation atherosclerosis and acute coronary syndromes in humans. Clin Endocrinol2009; 71:202-7. doi: org/10.1111/j.1365-2265.2008.03453.x.

27. Troseid M, Seljeflot I, Hjerkinn EM, Arnesen H. Interleukin 18 is a strong predictor of cardiovascular events in elderly men with the metabolic syndrome. Synergistic effect of inflammation and hyperglycemia. Diabetes Care2008. doi: org/10.2337/dc08-1710. 


\title{
Comparison of Serum Level and IL-18 Gene Expression and Reactive Protein in Patients with Type 2 Diabetes with Metabolic Syndrome and Healthy People
}

\author{
Yadolahifarsani $L^{1}$, Ziajahromi $N^{1^{*}}$, Vaezipour $M^{1,2}$ \\ (Received: December 31, 2018 \\ Accepted: May 11, 2019)
}

\begin{abstract}
Introduction: Metabolic syndrome is a common clinical anomaly, with an increased risk of developing type 2 diabetes and cardiovascular risk factors. Increased inflammatory mediators, such as reactive protein,as well as the inflammatory cytokines can be associated with the incidence and progression of metaboli syndrome and type 2 diabetes.
\end{abstract}

Materials \& Methods: This study was performed on 35 male and female patients with an average age of 55 years, type 2 diabetes mellitus with metabolic syndrome and 35 healthy subjects as control group. Separated serum samples were kept at $-20^{\circ}$ $\mathrm{C}$ for quantitative evaluation of serum IL18 by ELISA kit and C-reactive protein. RNA extraction from cells was performed by JenaBioscience kit and finally Gene expression assay was performed quantitatively using Real Time RTPCR.

Findings: The mean serum levels of IL-18 were significantly increased $(\mathrm{P}=0.008)$, and serum reactive protein $(\mathrm{P}<0.001)$ was significantly increased in patients with type 2 diabetes mellitus with metabolic syndrome compared with healthy subjects. Also, expression of IL-18 gene $(\mathrm{P}=0.003)$ in lymphocyte cells of type II diabetes patients with metabolic syndrome was significantly higher than healthy subjects.

Discussion \& Conclusions: The present study showed that patients with type 2 diabetes mellitus with metabolic syndrome have high levels of inflammatory factors such as IL-18 in their serum. it can be concluded that serum levels of IL-18, Creactive protein and $\mathrm{IL}-18$ expression play an important role in inflammatory response and progression. Type 2 diabetes and metabolic syndrome.

Keywords: Interleukin 18, C-reactive protein, Type II diabetes, Metabolic syndrome

1.Dept of Basic Science, Faculty of Biology, Shahrekord Branch, Islamic Azad University, Shahrekord, Iran,

2.Faculty of Medical Sciences, Shahid Beheshti University, Tehran, Iran,

*Corresponding author Email: n.zia@iaushk.ac.ir 